\title{
Kontribusi Intensitas Pemakaian Gadget dan Peran Orang Tua Terhadap Hasil Belajar Matematika Siswa Kelas V SD
}

\section{Christopher Damian Unisi Naibaho ${ }^{1}$, I Gusti Agung Ayu Wulandari ${ }^{1}$}

\author{
1 Universitas Pendidikan Ganesha, \\ Singaraja, Indonesia, \\ *e-mail: christopherdamianunisinaibaho@undiksha.ac.id
}

\begin{abstract}
Abstrak
Pemakaian gadget membantu siswa dan guru untuk tetap dapat melakukan kegiatan pembelajaran walaupun tidak bertemu secara langsung di dalam satu kelas. Namun, hal ini berarti siswa akan lebih sering untuk menggunakan gadget, yang tidak menutup kemungkinan siswa mengakses hal-hal lain diluar pembelajaran, maka dari itu peran dari orang tua sangatlah penting dalam mengawasi anaknya dalam penggunaan gadget sehari-hari. Penelitian ini bertujuan untuk mengkaji kontribusi yang diberikan intensitas pemakaian gadget serta peran orang tua terhadap hasil belajar matematika siswa kelas $\checkmark$ SD. Penelitian ini merupakan penelitian ex post facto. Populasi dalam penelitian ini berjumlah 361 siswa kelas V SD, sampel berjumlah 178 siswa. Pengumpulan data dalam penelitian ini menggunakan metode non-tes. Data intensitas pemakaian gadget dan peran orang tua didapatkan melalui penyebaran kuisioner, sedangkan data hasil belajar siswa didapat melalui pencatatan dokumen. Uji hipotesis dilakukan menggunakan analisis regresi linier sederhana dan regresi linier ganda. Hasil analisis menunjukkan bahwa intensitas pemakain gadget berpengaruh negatif dan signifikan terhadap hasil belajar matematika siswa kelas V SD dengan memberikan kontribusi sebesar $3,5 \%$, peran orang tua berpengaruh positif dan signifikan terhadap hasil belajar matematika kelas V SD sebesar 3\%. Sedangkan intensitas pemakaian gadget dan peran orang tua secara bersama-sama memberikan kontribusi sebesar $8 \%$. Jadi, intensitas penggunaan gadget dan peran pengawasan orang tua mempunyai konribusi terhadap hasil belajar matematika.
\end{abstract}

Kata kunci: gadget, peran orang tua, hasil belajar matematika

\begin{abstract}
Gadgets helped students and teachers to be able to carry out learning activities even though they did not meet directly in one class (Distance Learning Activity). However, this means students were use gadgets more often, which did not rule out the possibility that students will more often access other things outside of learning, therefore the role of parents was very important in supervising the children daily use of gadgets. This study aims to determine the amount of contribution given the intensity of using gadgets and the role of parents on mathematics learning outcomes of fifth grade elementary school students. This research is an ex post facto research. The population in this study was 361 students. The number of samples was determined using the proportional random sampling method. The samples are 178 students. Data collecting was using a non-test method. Data on the intensity of using gadgets and the role of parents were obtained through distributing questionnaires, while data on student learning outcomes was obtained through document recording. Hypothesis was analyzed using simple linear regression and multiple linear regression. The results of the analysis show that the intensity of gadget usage has a negative and significant effect on mathematics learning outcomes by contributing $3.5 \%$, the role of parents has a positive and significant effect on mathematics learning outcomes by $3 \%$. Meanwhile, the intensity of the use of gadgets and the role of parents together contributed $8 \%$ to mathematics learning outcome.
\end{abstract}

Keywords: gadget, role of parents, mathematic learning outcome 


\section{Pendahuluan}

Pandemi Covid-19 menjadi salah salah satu malah yang harus dihadapai oleh didia, adanya Covid-19 ini menuntut pemerintah mengambil kebijakan yang tepat untuk mencegah terjadi penularan Covid-19. Kebijakan-kebijan yang diambil olah pemerintah berdampak terhadap berbagai bidang kehidupan manusia. Salah satu bidang yang mengalami perubahan adalah bidang pendidikan, pembelajaran yang harusnya dilaksanakan secara tatap muka harus diubah menjadi pembelajaran daring (dalam jaringan) (Anugrahana, 2020; Dong et al., 2020; Mahitsa \& Mahardini, 2020; L. Mishra et al., 2020). Adanya pembelajaran daring memberikan kesempaan kepada siswa untuk tetap menyelesaikan pembelajaran walupun tanpa adanya proses tatap muka dengan kata lain adanya pembelajaran daring membuat siswa belajaran lebih mandiri (Hwang et al., 2020; Kkese, 2020; Lage-Cala et al., 2020). Untuk menghujudkan pembelajaran daring yang berkualitas membutuhkan persiapan yang baik dari guru, siswa dan orang tua. Hal ini mengingat pembelajaran daring harus didukung oleh fasitas seperti computer, gadget, dan internet selain fasiltas tersebut pembelajaran daring saat ini menggunkan alat bantu berupa google meet, google room, google classroom, WA, dan social media (Chang et al., 2020). Dengan fasiltas yang tersedia dan alat bantu yang bisa digunakan akan membuat pembelajaran daring berkualitas. pembelajaran online akan membantu peserta didik untuk memahami materi yang bersifat abstrak, mengembangkan pembelajaran kolaborasi, penalaran dan kegiatan pemecahan masalah (Arnott \& Yelland, 2020).

Namun, kenyataan dilapangan berbeda dengan yang diharapakan dimana, beberapa peserta didik yang tidak biasa menggunkan smart phone dan komputer dalam proses pembelajaran mengalami menurunnya minat belajar dan tidak memperhatikan pembelajaran online (D. L. Mishra et al., 2020). Dengan tidak adanya minat dalam proses pembelajaran membuat siswa melakukan aktivitas seperti seperti bermain game, social media dan lebih banyak menonton youtube serta kegiatan yang lain yang menunjukkan adanya kecanduan "gawe" (Liu et al., 2020; Rahmawati \& Latifah, 2020; Samaha \& Hawi, 2016). Aktivitas anak seperti bermain game didalam ruangan akan membuat anak kehilangan keinginan untuk berinteraksi dengan orang luar. Pembelajaran daring dapat menggangu perkembangan sosialnya dan emosional, kurangnya adanya interaksi sosial serta membahayakan kesehatan dan pertumbuhan (Edwards et al., 2012; O'Doherty et al., 2018).

Selain itu masalah pembelajaran daring adalah Kurang siapnya orang tua dalam menghadapi pembelajaran online, pembelajaran online tidak mempunyai suasan formal seperti pembelajaran tradisional, pada pembelajaran online tidak terjadi interaksi social sesama peserta didik (Dong et al., 2020). Kondisi ini didukung oleh hasil observasi yang dilakukan, dimana kebebasan siswa menggunakan gadget selama belajar di rumah menyebabkan timbulnya beberapa masalah. Cukup banyak orang tua yang mengeluh mengenai anaknya yang tidak mengenal waktu dalam menggunakan gadget terlebih lagi gadget digunakan tidak untuk mengakses situs belajar yang mendukung. Kebebasan dalam pengunaan gadget menyebabkan terjadinya perilaku konsutif (Ariston \& Frahasini, 2018), dampak yang lain adalah anak akan mengalami perubahan emosi, mudah marah, dan cendrung menirukan apa yang ditonton (Syifa et al., 2019).

Hasil penelitian dari (Pebriana, 2017) memaparkan bahwa penggunaan gadget tanpa pengawasan memang berdampak pada anak. Akan timbul rasa ketergantungan dalam menggunakan gadget yang memberikan efek negatif tidak hanya pada fokus anak dalam belajar tetapi juga dengan kemampuan anak dalam berinteraksi sosial. Novianti et al., (2020) juga menjelaskan bahwa saat ini penggunaan gadget oleh anak saat ini sudah lebih dari 1 jam diluar kepentingan belajar atau hanya untuk bermain. Tentunya hal ini tidak seperti yang diharapkan, mengingat saat ini gadget tidak bisa terlepas dari sarana belajar jarak jauh dan seharusnya sebagian besar penggunaan gadget oleh anak digunakan untuk belajar. Jadi, pembelajaran daring yang tidak bisa terlepsa dari alat komunikasi seperti computer, gadget akan berdampak positif dan juga berdampak negatif 
dampak negative dari pembelajaran daring, jika dibiarakan tentunya akan dihasilkan anak yang mempunyai prilaku yang tidak stabil dan lebih individual.

Saat ini solusi yang bisa dilakukan adalah dengan memperluas peranan orang tua dalam mengawasi anak dalam proses pembelajaran. Peranan orang tua saat ini sangat penting karena anak belajar di rumah bersama keluarga. Orang tua memegang peran penting dalam pendidikan anak (Lilawati, 2020). Peran orang tua dalam kegiatan pembelajaran sangatlah penting dimana dalam pembelajaran daring guru dapat dengan lengkap menjelaskan materi sehingga anak tentunya harus mendapat bimbingan dari orang tua untuk dapat membantunya dalam belajar (Asmuni, 2020). Dengan bimbingan dan pengawasan oaring tua tentunya anak akan menjadi lebih disiplin dalam melakukan pembelajaran daring dan penggunaan gadget.

Jabaran-jabaran tersebut memberikan gambaran bagaimana pentingnya gadget saat ini dan peranan orang tua dalam mengawasi pembelajaran daring. Sehingga penelitian yang bertujuan mengkaji kontribusi yang diberikan intensitas pemakaian gadget serta peran orang tua terhadap hasil belajar matematika siswa kelas V SD. Dengan mengetahui kondisi dilapangan berkaitan dengn pembelajaran daring akan membantu guru untuk menentukan langkah yang terbaik untuk menghasilkan pembelajaran daring yang berkualitas. Serta membantu orang tua dan guru untuk dapat meningkatkan hasil belajar matematika siswa selama proses pembelajaran daring dengan menjadikan gadget sebagai sarana belajar yang pemakaiannya dapat disesuaikan dengan kebutuhan.

\section{Metode}

Penelitian ini merupakan penelitian ex post facto dengan jenis studi korelasi. Variabel bebas dalam penelitian ini adalah intensitas pemakaian gadget (X1) dan peran orang tua (X2), sedangkan untuk variabel terikatnya adalah hasil belajar matematika (Y). Konstalasi penelitian di atas disusun guna menentukan hubungan intensitas pemakaian gadget dan peran orang tua terhadap hasil belajar matematika yang dilakukan menggunakan analisis korelasi sederhana dan ganda, dan besaran kontribusi ditentukan melalui besaran nilai koefisien determinasi.

Penelitian dilaksanakan terhadap siswa kelas V SD Gugus Letkol Wisnu Kecamatan Denpasar Utara Tahun Ajaran 2020/2021. Ketujuh sekolah tersebut adalah SDN 1 Peguyangan, SDN 3 Peguyangan, SDN 5 Peguyangan, SDN 6 Peguyangan, SDN 10 Peguyangan, SDN 11 Peguyangan, dan SDN 12 Peguyangan. Populasi dalam penelitian ini berjumlah 361 siswa yang tersebar dalam 7 sekolah. Jumlah sampel ditentukan menggunakan tabel Isaac and Michael, dengan melihat pada jumlah populasi serta taraf signifikansi $5 \%$ pada tabel tersebut maka didapat jumlah sampel yang digunakan dalam penelitian ini berjumlah 178 siswa.

Data dikumpulkan menggunakan metode non-tes yaitu, pencatatan dokumen serta penyebaran kuisioner. Metode pencatatan dokumen digunakan untuk mengumpulkan data terkait hasil belajar matematika siswa kelas V SD Gugus Letkol Wisnu Kecamatan Denpasar Utara, nilai yang digunakan adalah nilai matematika dari Penilaian Akhir Semester (PAS) Tahun Ajaran 2020/2021. Sedangkan kuisoner atau angket disebarkan untuk mengumpulkan data terkait dengan intensitas pemakaian gadget dan peran orang tua. Skala jawaban pernyataan menggunakan skala 4 likert, skala 4 dianggap lebih tepat digunakan guna menghindari keraguan dari responden dalam menjawab kuisioner. Kisikisi instrument angket disajikan pada tabel 1 dan 2 di bawah ini.

Tabel 1. Kisi-Kisi Intensitas Pemakaian Gadget Variabel Indikator

Intensitas Pemakaian Gadget Durasi pemakaian gadget sebagai media pembelajaran. 
Tabel 2. Kisi-Kisi Peran Orang Tua

\begin{tabular}{llrl}
\hline Variabel & Dimensi & Indikator \\
& & 1. & Memberi kesempatan kepada anak untuk \\
& Fasilitator & menggunakan gadget. \\
& & 2. Memenuhi kelengkapan belajar anak. \\
Peran & Motivator & 3emberikan dorongan motivasi belajar & pada anak. \\
Orang & & 4. Memantau perkembangan akademik \\
Tua & & anak. & \\
& Pembimbing & 5. Mengontrol waktu belajar anak \\
& & 6. Mengawasi anak dalam pemakaian & gadget \\
& & 7. Komunikasi yang baik. \\
\hline
\end{tabular}

Setelah data berhasil dikumpulkan, guna membuktikan keajegan dan keabsahan dari instrumen, selanjutnya dilakukan uji validitas konstruk, validitas butir, serta uji reliabilitas. Uji validitas butir diuji menggunakan uji product moment, dari hasil uji validitas butir, semua butir pernyataan yang berjumlah 3 butir pada instrument angket intensitas pemakaian gadget dinyatakan valid. Lalu untuk instrumen angket peran orang tua yang berjumlah 15 butir pernyataan, 1 butir pernyataan dinyatakan tidak valid. Uji reliabilitas menggunakan uji alpha cornbach, menyatakan bahwa instrumen angket instrumen intensitas pemakaian gadget dan peran orang tua memiliki tingkat reliabilitas yang tinggi.

Setelah data berhasil terkumpul, data kemudian diolah dan dianalisis menggunakan metode statistik deskriptif serta uji statistik inferensial. Adapun metode statistik deskriptif berupa mencari mean, standar deviasi, varian, skor maksimum dan minimum, distribusi skor, serta histogram arah regresi, semua dilakukan secara manual. Untuk mengukur tingkatan masing-masing variabel digunakan konversi skala lima. Uji prasyarat dilakukan sebelum dilaksanakan uji hipotesis, uji prasayarat yang dilakukan adalah, uji normalitas, uji linieritas, uji heterokedasisitas serta uji multikolinearitas.Setelah uji prasyarat terpenuhi selanjutnya dapat dilanjutkan dengan uji regresi dan uji korelasi. Untuk hipotesis I dan II di uji menggunakan analisis regresi linier sederhana, sedangkan untuk hipotesis III diuji menggunakan analisis regresi linier ganda

\section{Hasil dan Pembahasan}

Data hasil bellajar matematika siswa kelas V SD didapat melalui Teknik pencatatan dokumen dan bersumber dari nilai Penliaian Akhir Semester (PAS), sedangkan untuk data intensitas pemakaian gadget dan peran orang tua didapat melalui angket / kuisioner. Hasil analisis deskriptif ditunjukkan pada tabel 3 berikut.

Tabel 3. Deskripsi Data Hasil Belajar Matematika, Intensitas Pemakaian Gadget dan Peran

Tabel 3. Orang Tua Kelas V SD Gugus Letkol Wisnu Kecamatan Denpasar Utara.

\begin{tabular}{lccc}
\hline Analisis Statistik & $\begin{array}{c}\text { Hasil Belajar } \\
\text { Matematika }\end{array}$ & $\begin{array}{c}\text { Intensitas } \\
\text { Pemakaian Gadget }\end{array}$ & Peran Orang Tua \\
\hline Sampel & 178 & 178 & 178 \\
Skor Maksimum & 98 & 12 & 52 \\
Skor Minimum & 55 & 5 & 23 \\
Rata-Rata & 79,73 & 8,30 & 39,16 \\
Standar Deviasi & 9,86 & 1,62 & 4,29 \\
Varian & 97,4 & 2,62 & 18,46 \\
\hline
\end{tabular}

Berdasarkan tabel 3 tersebut, nilai rata-rata hasil belajar matematika siswa kelas $\mathrm{V}$ SD Gugus Letkol Wisnu Kecamatan Denpasar Utara sebesar 79,73, dengan mengacu pada tabel rentang tabel PAP, nilai tersebut berada pada kategori cukup baik. Untuk data 
intensitas pemakaian gadget nilai rata-ratanya adalah 8,30, apabila mengacu pada tabel kategori skala lima teoritik maka intensitas pemakaian gadget siswa kelas V SD Gugus Letkol Wisnu Kecamatan Denpasar Utara berada pada kategori tinggi.Sedangkan untuk data peran orang tua memiliki nilai rata-rata 39,16, apabila mengacu pada tabel skala lima teoritik, maka peran orang tua siswa kelas V SD Gugus Letkol Wisnu Kecamatan Denpasar Utara berda pada kategori cukup baik. Uji selanjutnya yang dilakukan adalah uji prasyarat.

Uji prasyarat yang pertama adalah uji noramalitas. Hasil analisis uji normalitas diperoleh variabel intensitas pemakaian gadget, nilai $F_{T-} F_{S}=0,100<\mathrm{KS}$ tabel $=0,101$, berdasarkan nilai tersebut dapat disimpulkan data intensitas pemakaian gadget berdistribusi normal. Pada data variabel peran orang tua nilai $F_{T-} F_{S}=0,099<\mathrm{KS}$ tabel $=$ 0,101 , berdasarkan nilai tersebut dapat disimpulkan data peran orang tua berdistribusi normal. Untuk variabel hasil belajar matematika nilai $F_{T-} F_{S}=0,097<\mathrm{KS}$ tabel $=0,101$, berdasarkan nilai tersebut dapat disimpulkan data hasil belajar matematika berdistribusi secara normal. Data yang sudah normal dilanjutkan ke uji Linearitas. Hasil uji linearitas diperoleh variabel intensitas pemakaian gadget dengan hasil belajar matematika didapat $\mathrm{F}$ Tuna Cocok $(\mathrm{TC})=1,337<\mathrm{F}$ tabel $=2,152$ pada taraf signifikansi $5 \%$, hasil uji menyatakan nilai F TC lebih rendah dari nilai $F$ tabel, maka dapat disimpulkan variabel intensitas pemakaian gadget terhadap hasil belajar matematika linear. Sedangkan untuk hasil pengujian antara variabel peran orang tua terhadap hasil belajar matematika diperoleh hasil $\mathrm{F} \mathrm{TC}=0,69<\mathrm{F}$ tabel $=1,638$ pada taraf signifikan $5 \%$, maka dapat disimpulkan variabel peran orang tua terhadap hasil belajar matematika linear.

Selanjutnya uji prasyarat yang dilakukan adalah uji multikolinearitas dan uji heterokedastisitas. Dimana hasil uji multikolinearitas diperoleh hasil Tolerance pada variabel intensitas pemakaian gadget dan peran orang tua adalah 0,951 $>0,01$, serta nilai VIF pada variabel intensitas pemakaian gadget dan peran orang tua sebesar 1,052 <10. Dari nilai tersebut menandakan bahwa tidak terjadi multikolinearitas diantara variabel intensitas pemakaian gadget dan peran orang tua. Sedangkan, uji heterokedastisitas diperoleh pada variabel intensitas pemakaian gadget nilai Sig. (2-tailed) $=0,881>\alpha 0,05$ maka dapat dikatakan tidak terjadi heterokedastisitas pada variabel tersebut. Sedangkan untuk variabel peran orang tua nilai Sig. (2-tailed) $=0,639>\alpha 0,05$ maka dapat disimpulkan pula tidak terjadi gejala heterokedastisitas pada variabel peran orang tua. Karena semua uji prasyarat telah terpenuhi maka uji hipotesis menggunakan analisis linier sederhana dan analisis linier berganda dapat dilakukan. Hasil uji analisis dalam penelitian ini disajikan pada tabel 4 berikut.

Tabel 4. Ringkasan Hasil Analisis Data

\begin{tabular}{cccc}
\hline $\begin{array}{c}\text { Hubungan } \\
\text { Antar } \\
\text { Variabel }\end{array}$ & Garis Persamaan Regresi & $\begin{array}{c}\text { Koefisen } \\
\text { Korelasi }\end{array}$ & Kontribusi \\
\hline $\begin{array}{c}\mathrm{X} 1 \text { terhadap } \\
\mathrm{Y}\end{array}$ & $\breve{\mathrm{Y}}=88,96-1,147 \mathrm{X}_{1}$ & $-0,188$ & $3,5 \%$ \\
$\begin{array}{c}\mathrm{X} 2 \text { terhadap } \\
\mathrm{Y}\end{array}$ & $\overline{\mathrm{Y}}=64,15+0,398 \mathrm{X}_{2}$ & 0,148 & $3 \%$ \\
$\begin{array}{c}\mathrm{X} 1 \text { dan } \mathrm{X} 2 \\
\text { terhadap } \mathrm{Y}\end{array}$ & $\breve{\mathrm{Y}}=71,056-1,451 \mathrm{X}_{1}+0,520 \mathrm{X}_{2}$ & 0,290 & $8,4 \%$ \\
\hline
\end{tabular}

Berdasarkan tabel 4 tersebut, diperoleh beberapa temuan, Temuan pertama adalah pengujian hipotesis I menggunakan analisis regresi linier sederhana didapat hasil persamaan sebagai berikut $\hat{Y}=88,96-1,147 \mathrm{X}_{1}$ signifikan dan linier dengan nilai $\mathrm{F}$ hitung $=6,46>\mathrm{F}$ tabel $=3,89$ sehingga $\mathrm{H}_{\mathrm{O}}$ ditolak dan $\mathrm{H}_{\mathrm{a}}$ diterima, dimana terdapat pengaruh yang signifikan antara variabel intensitas pemakaian gadget dan hasil belajar matematika 
siswa kelas V SD Gugus Letkol Wisnu Kecamatan Denpasar Utara Tahun Ajaran 2020/2021. Dari garis persamaan tersebut menyatakan intensitas pemakaian gadget memberikan pengaruh negatif yang signifikan terhadap hasil belajar matematika, dengan setiap kenaikan 1 skor intensitas pemakaian gadget maka hasil belajar matematika akan menurun sebesar 1,147. Namun sebaliknya apabila terjadi penurunan 1 skor intensitas pemakaian gadget maka hasil belajar matematika akan naik sebesar 1,147 hal ini sesuai dengan hasil hitung nilai korelasi $\left(\mathrm{r}_{\mathrm{xy}}\right)=-0,188<\mathrm{r}$ tabel $=0,148$, yang artinya menyatakan korelasi antara intensitas pemakaian gadget tidak signifikan, sehingga intensitas pemakaian gadget dan hasil belajar matematika memiliki hubungan yang negatif sehingga semakin naik nilai $X$ akan berakibat penurunan pada nilai $Y$. Dengan nilai koefisien determinasi $\mathrm{R}^{2}=0,035$ maka besar kontribusi intensitas pemakaian gadget terhadap hasil belajar matematika sebesar $3,5 \%$ sedangkan untuk $96,5 \%$ sisanya dijelaskan oleh variabel lain diluar penelitian ini.

Temuan kedua adalah pengujian hipotesis II di uji menggunakan analisis regresi linier sederhana dengan hasil persamaan $\hat{Y}=64,15+0,398 \mathrm{X}_{2}$ signifikan dan linier dengan nilai $F$ hitung $=5,448>F$ tabel $=3,89$, sehingga $\mathrm{H}_{0}$ ditolak dan $\mathrm{H}_{\mathrm{a}}$ diterima, dimana terdapat pengaruh yang signifikan antara variabel peran orang tua dan hasil belajar matematika siswa kelas V SD Gugus Letkol Wisnu Kecamatan Denpasar Utara Tahun Ajaran 2020/2021. Melalui persamaan garis regresi tersebut setiap kenaikan 1 skor peran orang tua akan menaikkan skor hasil belajar matematika siswa sebesar 0,398. Sehingga dapat disimpulkan peran orang tua secara nyata dapat memperikan dampak positif terhadap hasil belajar matematika anak. Uji korelasi yang menunjukkan $\left(r_{x y}\right)=$ $0,173>r$ tabel $=0,148$, sehingga hasil korelasi signifikan dimana terdapat hubungan yang postiif antara peran orang tua terhadap hasil belajar matematika. Dengan nilai koefisien determinasi $\mathrm{R}^{2}=0,03$ maka besar kontribusi peran orang tua terhadap hasil belajar matematika sebesar $3 \%$ sedangkan untuk $97 \%$ sisanya dijelaskan oleh variabel lain diluar penelitian ini.

Temuan ketiga, adalah pengujian hipotesis III dilakukan menggunakan uji analisis regresi linier ganda dengan hasil persamaan $\hat{Y}=71,056-1,451 \mathrm{X}_{1}+0,520 \mathrm{X}_{2}$ signifikan dan linier, hal ini menjelaskan intensitas pemakaian gadget memberikan pengaruh negatif terhadap hasil belajar matematika dimana setiap kenaikan 1 skornya akan berdampak pada penurunan skor hasil belajar matematika sebesar 1,451 dan sebaliknya. Kemudian untuk peran orang tua memberikan pengaruh positif terhadap hasil belajar matematika dimana setiap kenaikan 1 skornya akan berdampak pada kenaikan skor hasil belajar matematika sebesar 0,520 . Dengan nilai $F$ hitung $=8,031>F$ tabel $=3,04$ sehingga sehingga $\mathrm{H}_{0}$ ditolak dan $\mathrm{H}_{a}$ diterima, dimana terdapat pengaruh yang signifikan antara variabel intensitas pemakaian gadget dan peran orang tua secara bersama-sama terhadap hasil belajar matematika siswa kelas V SD Gugus Letkol Wisnu Kecamatan Denpasar Utara Tahun Ajaran 2020/2021, dengan nilai korelasi yang signifikan dimana $\mathrm{R}_{\mathrm{y}(1,2)}=0,290>\mathrm{r}$ tabel $=0,148$. Dengan nilai koefisien determinasi $\mathrm{R}^{2}=0,0841$ maka besaran kontribusi yang diberikan oleh intensitas pemakaian gadget dan peran orang tua sebesar $8,4 \%$, sedangkan 91,6 sisanya dijelaskan oleh variabel lain diluar penelitian ini.

\section{Pembahasan}

Pertama, berdasarkan hasil penelitian yang sudah dijabarkan sebelumnya, dapat dikatakan bahwa hasil belajar matematika siswa dipengaruhi oleh intensitas pemakain gadget sebesar 3,5\%. Penggunaan gadget saat ini bukanlah hal yang asing dalam pembelajaran daring. Saat pembelajaran daring segala tugas materi akan diberikan oleh guru menggunakan computer, gadget, dan internet selain fasiltas tersebut pembelajaran daring saat ini menggunkan alat bantu berupa google meet, google room, google classroom, WA, dan social media (Chang et al., 2020). Penggunaan fasilitas dengan tepat dan sesuai dengan kebutuhan pembelajaran daring tentunya akan berdampak baik terhadap proses pembelajaran (Rahmanto \& Bunyamin, 2020). Sebaliknya Intensitas pemakain gadget yang tidak sesuai dengan kebutuhan akan berdampak negative. 
Dimana siswa cenderung menggunakan gadgetnya untuk aktivitas hiburan lain diluar kegiatan pembelajaran seperti bermain game, menonton video, dan segala aktivitas lain yang tidak terkait dengan pembelajaran. Sehingga anak akan lebih malas untuk belajar, malas dan menunda-nunda untuk mengerjakan tugas dari guru, dan lebih memilih untuk bermain dengan menggunakan gadgetnya. Dengan tidak adanya minat dalam proses pembelajaran membuat siswa melakukan aktivitas seperti seperti bermain game, social media dan lebih banyak menonton youtube serta kegiatan yang lain yang menunjukkan adanya kecanduan "gawe" (Liu et al., 2020; Rahmawati \& Latifah, 2020; Samaha \& Hawi, 2016) selain itu dengan intensitas penggunaan gadget yang tinggi dan tidak sesuai dengan peruntukkanya akan berdampak terhadap emosi dan prilaku anak dalam kehidupan sehari-hari (Ariston \& Frahasini, 2018; Syifa et al., 2019). Kondisi ini sesaui dengan hasil penelitian yang dilakukan oleh Syifa et al., (2019) dimana gadget memberikan pengaruh negatif terhadap perkembangan anak terutama dalam perkembangan moralnya, yaitu anak anak menjadi malas melakukan apapun, malas untuk beribadah, serta waktu belajar anak semakin berkurang akabat dari sering bermain game dan menonton youtube. Hasil penelitian dari (Pebriana, 2017) memaparkan bahwa penggunaan gadget tanpa pengawasan memang berdampak pada anak. Akan timbul rasa ketergantungan dalam menggunakan gadget yang memberikan efek negatif tidak hanya pada fokus anak dalam belajar tetapi juga dengan kemampuan anak dalam berinteraksi sosial. Novianti et al., (2020) juga menjelaskan bahwa saat ini penggunaan gadget oleh anak saat ini sudah lebih dari 1 jam diluar kepentingan belajar atau hanya untuk bermain. Tentunya hal ini tidak seperti yang diharapkan, mengingat saat ini gadget tidak bisa terlepas dari sarana belajar jarak jauh dan seharusnya sebagian besar penggunaan gadget oleh anak digunakan untuk belajar. Rozalia, (2017) menyatakan bahwa terdapat hubungan negatif yang tidak signifikan antara intensitas pemanfaatan gadget dengan prestasi belajar siswa. Jadi dapat dikatakan bahwa dengan intensitas penggunaan gadget tinggi tidak selalu berdanpak positif terhadap hasil belajar.

Kedua, dari hasil penelitian yang telah dijabarkan di atas menunjukkan peran orang tua memberikan pengaruh yang positif pada hasil belajar matematika anak, sehingga membuktikan bahwa orang tua memiliki peranan penting dalam perkembangan akademik anak mereka. Melalui hasil penelitian ini dapat disimpulkan bahwa orang tua siswa kelas V SD Gugus Letkol Wisnu telah melaksankan peran mereka sebagai fasilitator, motivator, dan pembimbing bagi anak mereka dan memberikan kontribusi yang positif dalam pembelajaran anak. Walaupun pembelajaran matematika terlihat sulit, kehadiran orang tua untuk memberikan bantuan dalam belajar anak sangat berpengaruh pada perkembangan akademiknya. Sehingga orang tua harus memaksimalkan peran mereka terutama orang tualah yang memiliki waktu banyak dalam berinteraksi dengan anak. Peran orang tua dalam kegiatan pembelajaran sangatlah penting dimana dalam pembelajaran daring guru dapat dengan lengkap menjelaskan materi sehingga anak tentunya harus mendapat bimbingan dari orang tua untuk dapat membantunya dalam belajar (Asmuni, 2020; Lilawati, 2020). Orang tua yang mampu mendukung dan membimbing anak dalam proses pembelajaran akan membuat hasil belajar siswa meningkat. Hal ini sesuai dengan pendapat Ningrum, (2018) bahwa prestasi belajar siswa dapat ditingkatkan melalui peran serta pola asuh orang tua yang diterapkan oleh orang di rumah terhadap siswa. Terdapat hubungan yang positif dan signifikan pola asuh orang tua dengan kompetensi pengetahuan matematika (Juniarti et al., 2020). Jadi, peran orang tua dalam pembelajaran daring sangat penting, dan sangat mempengaruhi proses pembelajaran karena saat ini siswa lebih banyak belajar dirumah dengan bimbingan orang tua.

Ketiga, dari hasil penjabaran penelitian di atas dapat disimpulkan bahwa intensitas pemakaian gadget dan peran orang tua merupakan dua hal yang saling berkaitan satu dengan yang lainnya, keduanya merupakan faktor eksternal dari diri siswa yang mempengaruhi hasil belajar, terutama dalam mata pelajaran matematika. Penggunaan gadget membantu siswa untuk membantu mencari bahan pembelajaran dan orang tua 
memberikan perannya sebagai fasilitator, motivator, serta pembimbing dalam kegiatan belajar anak. Intensitas pemakaian gadget memberikan pengaruh yang negatif terhadap hasil belajar matematika anak, sehingga perlu adanya pengawasan yang kuat serta perlu pehatian yang lebih bagi orang tua dalam menjalankan fungsi peran mereka sebagai pembimbing bagi anak untuk dapat lebih mengawasi anaknya dalam penggunaan gadget. Penggunaan gadget tanpa pengawasan memang berdampak pada anak (Pebriana, 2017). Akan timbul rasa ketergantungan dalam menggunakan gadget yang memberikan efek negatif tidak hanya pada fokus anak dalam belajar tetapi juga dengan kemampuan anak dalam berinteraksi sosial. Selian itu dengan Anaya pengawasan orang tua dalam menggunakan gadget akan memberikan dampak terhadap meningkatan motivasi siswa dalam proses pembelajaran (Fenia, 2019). Jadi dapat dikatakan bahwa dengan pengawasan orang tua dalam penggunaan gadget akan memberikan dampak yang positif terhadap proses pembelajaran.

\section{Simpulan}

Dari hasil penelitian didapat bahwa intensitas pemakaian gadget berpengaruh negatif terhadap hasil belajar matematika, dengan makna semakin tinggi siswa dalam menggunakan gadgetnya tentu akan berdampak pada penurunan nilainya, terutama dalam pelajaran matematika. Hal ini dapat disimpulkan bahwa anak cenderung lebih menggunakan gadgetnya untuk hal-hal diluar kegiatan pembelajaran yang bermakna bagi mereka, dengan melihat peran orang tua yang berpengaruh secara postif terhadap hasil belajar anak, dapat disimpulkan pula bahwa peran orang tua memegang peranan penting bagi perkembangan anak mereka terutama dalam perkembangan akademiknya, sehingga orang tua diharapkan agar lebih mampu mengoptimalkan perannya sebagai fasilitator, motivator dan pembimbing dalam tumbuh kembang akademik anak sebagai contoh dalam membantu anak dalam mengajarkan mata pelajaran matematika yang dianggap sulit bagi anak, serta membimbing dan mengawasi anak dalam hal penggunaan gadget itu sendiri sehingga pemakaian gadget dapat lebih dioptimalkan sebagai alat yang memberi kemudahan bagi anak untuk belajar dan berprestasi dan bukan sebaliknya.

\section{Daftar Pustaka}

Anugrahana, A. (2020). Hambatan, Solusi dan Harapan: Pembelajaran Daring Selama Masa Pandemi Covid-19 Oleh Guru Sekolah Dasar. Scholaria: Jurnal Pendidikan Dan Kebudayaan, 10(3), https://ejournal.uksw.edu/scholaria/article/view/4033

Ariston, Y., \& Frahasini, F. (2018). Dampak Penggunaan Gadget Bagi Perkembangan Sosial Anak Sekolah Dasar. Journal of Educational Review and Research, 1(2), 86. https://doi.org/10.26737/jerr.v1i2.1675

Arnott, L., \& Yelland, N. (2020). Multimodal lifeworlds: Pedagogies for play inquiries and explorations. Journal of Early Childhood Education Research, 9(1), 124-146.

Asmuni. (2020). Problematika Pembelajaran Daring di Masa Pandemi Covid-19 dan

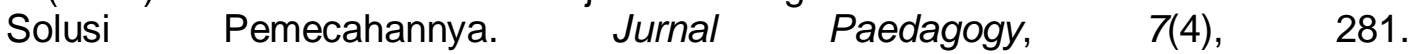
https://doi.org/10.33394/jp.v7i4.2941

Chang, T. Y., Hong, G., Paganelli, C., Phantumvanit, P., Chang, W. J., Shieh, Y. S., \& Hsu, M. L. (2020). Innovation of dental education during COVID-19 pandemic. Journal of Dental Sciences, 155. https://doi.org/10.1016/j.jds.2020.07.011

Dong, C., Cao, S., \& Li, H. (2020). Young children's online learning during COVID-19 pandemic: Chinese parents' beliefs and attitudes. Children and Youth Services Review, 118(June), 105440. https://doi.org/10.1016/j.childyouth.2020.105440

Edwards, S., Skouteris, H., Rutherford, L., \& Cutter-Mackenzie, A. (2012). 'It's all about Ben $10^{\mathrm{TM}}$ : Children's play, health and sustainability decisions in the early years. ,. 
Early Child Development and Care, 183(2), 280-293. https://doi.org/https://doi.org/10.1080/03004430. 2012.671816.

Fenia, M. (2019). Analisis Pola Asuh Orang Tua, Penggunaan Gadget, Dan Motivasi Belajar Siswa Kelas V. Joyful Learning Journal, 8(2), 79-83. https://doi.org/10.15294/jlj.v8i2.28981

Hwang, G. J., Wang, S. Y., \& Lai, C. L. (2020). Effects of a social regulation-based online learning framework on students' learning achievements and behaviors in mathematics. Computers and Education, 160, 104031. https://doi.org/10.1016/j.compedu.2020.104031

Juniarti, N. K. R., Margunayasa, I. G., \& Kusmariyatni, N. (2020). Hubungan Antara Pola Asuh Orang Tua dan Konsep Diri dengan Kompetensi Pengetahuan Matematika Siswa. Jurnal Ilmiah Sekolah Dasar, 4(1), 17. https://doi.org/10.23887/jisd.v4i1.24273

Kkese, E. (2020). McGurk effect and audiovisual speech perception in students with learning disabilities exposed to online teaching during the COVID-19 pandemic. Medical Hypotheses, 144(July), 110233. https://doi.org/10.1016/j.mehy.2020.110233

Lage-Cala, S., Folgueras-Díaza, M. B., Alonso-Hidalgoa, M., García-Menéndezb, D., \& Fernández-Garcíab, F. J. (2020). Investigation of the effectiveness of online learning tools for energy performance certificates preparation. Energy Reports, 6, 609-614. https://doi.org/10.1016/j.egyr.2019.09.034

Lilawati, A. (2020). Peran Orang Tua dalam Mendukung Kegiatan Pembelajaran di Rumah pada Masa Pandemi. Jurnal Obsesi: Jurnal Pendidikan Anak Usia Dini, 5(1), 549. https://doi.org/10.31004/obsesi.v5i1.630

Liu, Q., Huang, J., \& Zhou, Z. (2020). Self-expansion via smartphone and smartphone addiction tendency among adolescents: A moderated mediation model. Children and Youth Services Review, 119(June), 105590. https://doi.org/10.1016/j.childyouth.2020.105590

Mahitsa, M., \& Mahardini, A. (2020). Analisis Situasi Penggunaan Google Classroom pada Pembelajaran Daring Fisika. Jurnal Pendidikan Flsika, VIII(2), 215-224. https://doi.org/http://dx.doi.org/10.24127/jpf.v8i2.3102 ANALISIS

Mishra, D. L., Gupta, D. T., \& Shree, D. A. (2020). Online Teaching-Learning in Higher Education during Lockdown Period of COVID-19 Pandemic. International Journal of Educational Research Open, 100012. https://doi.org/10.1016/j.ijedro.2020.100012

Mishra, L., Gupta, T., \& Shree, A. (2020). Online teaching-learning in higher education during lockdown period of COVID-19 pandemic. International Journal of Educational Research Open, June, 100012. https://doi.org/10.1016/j.ijedro.2020.100012

Ningrum, W. R. (2018). Pengaruh Peranan Dan Pola Asuh Orang Tua Terhadap Hasil Belajar Siswa Sekolah Dasar Negeri (Sdn) Di Kecamatan Bogor Barat. Jurnal Pendidikan, 17(2), 129-137. http://jurnal.ut.ac.id/index.php/JP/article/view/621

Novianti, R., Puspitasari, E., Solfiah, Y., Febrialismanto, Maria, I., \& Garzia, M. (2020). Readiness in Teaching Science: Early Childhood Education Teacher's Online Experience. Journal of Physics: Conference Series, 1655(1). https://doi.org/10.1088/1742-6596/1655/1/012065

O'Doherty, D., Dromey, M., Lougheed, J., Hannigan, A., Last, J., \& McGrath1, D. (2018). Barriers and solutions to online learning in medical education - an integrative 
review. BMC Medical Education, 18(130), 1-11. https://doi.org/https://doi.org/10.1186/s12909-018-1240-0

Pebriana, P. H. (2017). Analisis Penggunaan Gadget terhadap Kemampuan Interaksi Sosial pada Anak Usia Dini. Jurnal Obsesi: Jurnal Pendidikan Anak Usia Dini, 1(1), 1. https://doi.org/10.31004/obsesi.v1i1.26

Rahmanto, M. A., \& Bunyamin. (2020). Efektivitas media pembelajaran daring melalui Google Classroom. Jurnal Pendidikan Islam, 11(November), 119-135. https://doi.org/https://doi.org/10.22236/jpi.v11i2.5974

Rahmawati, M., \& Latifah, M. (2020). Penggunaan Gawai, Interaksi Ibu-Anak, Dan Perkembangan Sosial-Emosional Anak Prasekolah. Jur. IIm. Kel. \& Kons., 13(1), 75-86. $\quad$ https://doi.org/DOI: http://dx.doi.org/10.24156/jikk.2020.13.1.75 PENGGUNAAN

Rozalia, M. F. (2017). Hubungan Intensitas Pemanfaatan Gadget Dengan Prestasi Belajar Siswa Kelas V Sekolah Dasar. Jurnal Pemikiran Dan Pengembangan Sekolah Dasar (JP2SD), 5(2), 722. https://doi.org/10.22219/jp2sd.vol5.no2.722-731

Samaha, M., \& Hawi, N. S. (2016). Computers in Human Behavior Relationships among smartphone addiction, stress, academic performance, and satisfaction with life. Computers in Human Behavior, 57, 321-325. https://doi.org/10.1016/j.chb.2015.12.045

Syifa, L., Setianingsih, E. S., \& Sulianto, J. (2019). Dampak Penggunaan Gadget terhadap Perkembangan Psikologi pada Anak Sekolah Dasar. Jurnal IImiah Sekolah Dasar, 3(4), 538. https://doi.org/10.23887/jisd.v3i4.22310 